This is the author's manuscript for publication. The publisher-formatted version may be available through the publisher's web site or your institution's library.

\title{
Visualizing the Influence of Geography, Oil and Geopolitics on Civil Wars in the Arab World: A Novel Application of Self- Organizing Maps and Duration Models
}

Mohamed M. Mostafa and Mohaned T. Al-Hamdi

\section{How to cite this manuscript}

If you make reference to this version of the manuscript, use the following information:

Mostafa, M. M., \& Al-Hamdi, M. T. (2014). Visualizing the influence of geography, oil and geopolitics on civil wars in the arab world: A novel application of self-organizing maps and duration models.

\section{Published Version Information}

Citation: Mostafa, M. M., \& Al-Hamdi, M. T. (2014). Visualizing the influence of geography, oil and geopolitics on civil wars in the arab world: A novel application of selforganizing maps and duration models. Civil Wars, 16(2), 239-254.

Digital Object Identifier (DOI): 10.1080/13698249.2014.927704

Publisher's Link:

http://www.tandfonline.com/doi/abs/10.1080/13698249.2014.927704?journalCode=fciv2 0\#.VElwg IdVd8

This item was retrieved from the K-State Research Exchange (K-REx), the institutional repository of Kansas State University. K-REx is available at http://krex.ksu.edu 


\title{
Visualizing the influence of geography, oil and geopolitics on civil wars in the Arab world: A novel application of self-organizing maps and duration models
}

\author{
Mohamed Mustafa and Mohaned T. Al-Hamdi
}

\begin{abstract}
The aim of this paper is to investigate why some internal conflicts are terminated quickly while others linger for several decades without a looming resolution in the horizon. In an attempt to achieve this objective the role played by geopolitical factors in the Arab world's internal conflicts was investigated. More specifically, we used Kohonen self-organizing maps, an artificial intelligence- based neural network technique, along with event duration models to investigate the role played by distance from the capital, access to international borders, terrain, valuable natural resources such as oil, and rebels fighting capability in civil wars in the Arab world. Using recently validated data spanning more than 50 years of Arab civil wars (19482003), our findings indicate that previously ignored geopolitical factors seem to play an important role in the duration of internal conflicts in the Arab World.
\end{abstract}

Keywords: Arab civil wars; duration models; self-organizing maps; geopolitics; oil resources

\section{Introduction}

Civil wars generally encompass three major parties: the existing government, at least one group of internal insurgents and possibly external actors who might intervene at a specific point in time in the internal conflict going on between the first two parties. In a study spanning around 70 years, it has been found that while a quarter of internal conflicts end in less than eight months, another quarter lasts more than five years and some civil wars linger for decades (Cunningham, $2006^{1}$ ). In the Arab world context the southern secessionist movement in Yemen was crushed in less than three months in 1994, while the Israel-Palestine conflict lasted 20,088 days at the end of 2003 (Buhaug, Gates \& Lujala, $2009^{2}$ ). In order to investigate why some internal conflicts are terminated quickly while others linger for several decades without a looming resolution we use 
SOM and duration models to understand the reason behind this wide variation in the duration of internal conflicts in the Arab world.

Lacina and Gleditsch's (2005) ${ }^{3}$ data on battle deaths during internal conflicts reveal that an internal conflict that lasts for up to two years yields on average around 3,000 deaths, while a conflict that lasts longer than two years generates on average around 44,000 deaths. In fact the international community has recently been directly or indirectly involved in several Arab civil wars, including Libya and the Sudan. Such interventions carry a significant cost both in terms of the loss of life and the monetary cost resulting from peacekeeping operations. Thus, understanding why some Arab civil wars lasts significantly more than the others is an important topic both at the theoretical and practical levels. At the theoretical level, investigating why some internal conflicts are terminated quickly while others linger for several decades without a looming resolution in the horizon inherently involves deep understanding regarding the causes of fighting and the underlying reasons behind cooperation to end the civil conflict. At the practical level, finding an answer to this question might help policy-makers in designing more feasible responses to such conflicts.

In this research we aim to contribute to the civil war duration literature by solely focusing on the geopolitical dynamics of internal conflicts in the Arab world. In fact several authors argued that there has been "a tendency to neglect the spatial context" in civil wars (Buhaug \& Rod, ${ }^{4}$ ). In a similar vein, Schutte and Weidmann $(2011)^{5}$ argued that the geographic aspect of civil wars has not been systematically examined because of the failure to understand how insurgent activities unfold in time-space domains. To remedy this void in the literature we focus on factors such as distance from the capital, terrain, natural resources and rebels fighting capabilities in an attempt to explain the duration of internal conflicts in the Arab world. Following Fearon's (2004) ${ }^{6}$ seminal work on civil war duration, the Arab civil wars analyzed in this study satisfied the following criteria: (1) They involved fighting between a state/claimants to a state and a rebel group/non-state group who sought either to take power or to change state's policies; (2) The conflict resulted in at least 1,000 people over its duration; and (3) The conflict resulted in killing at least 100 people on both sides, including civilians killed by fighting rebels. The last condition is aimed at ruling out possible massacres in the absence of organized opposition. This research is organized as follows. Next section presents the literature review and the study hypotheses. The research design and methodology aspects follow. The next section presents the results, while the final section discusses the research findings, implications and deals with avenues for future research. 


\section{Literature review and hypotheses development}

\subsection{Distance from the capital}

Herbst (2000) ${ }^{7}$ argues that distance plays a significant role in the geopolitics of internal civil conflicts since operating militarily over long distances puts the government troops in a clear disadvantage compared to the insurgents normally operating in remote areas. This problem might be exacerbated by logistical obstacles the government faces in internal conflicts involving distance areas. Other factors such as cost and lack of government support in remote areas controlled by insurgents might also explain the role of distance in civil wars duration (Buhaug, Gates and Lujala, $2009^{8}$ ).

Although there are few studies empirically investigating the role of distance in civil wars duration, these studies have generally found a positive relationship between distance and internal conflict duration. For example, Balch-Lindsay and Enterline ${ }^{9}$ found that separatist conflicts located in remote regions last longer. This finding has been corroborated by other studies, including Buhaug and Gates (2002) ${ }^{10}$ and Fearon and Laitin (2003) ${ }^{11}$. Buhaug and Rod (2006) 12 argue that the reason behind the positive relationship between distance and internal conflict duration might result from the government's inability to control the hinterlands "because of the sheer distance from the center of state power." (p. 318). This discussion suggests the following hypothesis:

H1: The further the conflict from the capital, the longer the duration of the civil war.

\subsection{Access to international border}

Rustad, Rod, Larsen and Gleditsch (2008) ${ }^{13}$ found that access to an international border, which is located far from the political center is more likely to affect the internal conflict. Moreover, often rebels seek protection in a neighboring country making it almost impossible for the government's troops to operate. This affects the government's army efficiency and makes it harder to end the internal conflict quickly. In several recent Arab internal conflicts, the main rebel groups such as the Polisario in the case of Morocco operate from bases beyond the national 
boundaries. This usually happens with the tacit support from the neigboring regime (Algeria). In fact several studies have found that the border length and interstate contiguity play an important role in internal conflicts' duration (e.g. Murdoch and Sandler, $2002{ }^{14}$; Ward and Gleditsch, 2002 ${ }^{15}$; Buhaug, Gates and Lujala, $2009^{16}$ ). This discussion suggests the following hypothesis:

$\mathrm{H} 2$ : The nearer the conflict to an international border, the longer the duration of the civil war.

\subsection{Rough terrain}

The rough terrain hypothesis postulates that mountains, forests, jungles and swamps provide insurgents with shelter from the less mobile government forces and facilitates guerrilla war tactics, which increases the duration of internal civil conflicts. Several case studies, including Burma, the Democratic Republic of Congo and Cambodia found a positive relationship between forest resources and duration of civil war (e.g. FAO, ${ }^{17}$ ). However, Ross (2006) ${ }^{18}$ noted that despite the importance of rough terrain in civil wars, this relationship has not been tested statistically. At the empirical level, Buhaug and Lujala (2005) ${ }^{19}$ found the amount of mountainous terrain in the country relates positively to the duration of civil conflicts. However, the forest coverage in a country was found to be negatively related to the civil war duration. Collier and Hoeffler (2004) ${ }^{20}$ merged both mountains and forests to represent rough terrain. Despite the fact that the authors found positive relationship between rough terrain and the duration of civil wars, this relationship did not reach statistical significance. Rustad, Rod, Larsen and Gleditsch (2008) ${ }^{21}$ also found that conflict zones with large areas of forest have, on average, longer conflicts. This discussion suggests the following hypothesis:

H3: The rough the terrain, the longer the duration of the civil war.

\subsection{Rebel capability}

Several studies have empirically tested the relationship between rebel capability and the duration of civil wars (e.g. Buhaug, Gates \& Lujala, $2009^{22}$; Cunningham, Gleditsch \& Salehyan, 2009 ${ }^{23}$ ). Most of this empirical work has found that weak rebels increase the duration of internal conflict. The theoretical underpinnings of this preposition are based on several factors. First, 
reaching a peaceful settlement between the government and rebels may be more costly compared to keeping the intensity of the conflict at an acceptable level for both parties (Walter, $2006^{24}$ ). This is because crushing rebel groups that employ guerrilla tactics might be a considerable task that involves high military and economic cost. Because of fear of reprisals, rebels also might be reluctant to lay down arms even if they know that their objectives are unattainable. On the other hand, strong rebels may either defeat the government's army or force the government to reach a peaceful settlement that quickly ends the conflict. This discussion suggests the following hypothesis:

H4: The weaker the rebels involved in the conflict, the longer the duration of the civil war.

\subsection{Oil and natural resources}

The relationship between natural resource dependence and civil war duration has been investigated extensively in the internal conflict literature. The direct link stream of literature argue that valuable natural resources such as oil and gas can easily be exploited by rebels in financing their arms purchase and their recruitment opportunities (e.g. Addison, Le Billon \& Murshed, $2002^{25}$; Auty, $2004^{26}$; Collier \& Hoeffler, $2004{ }^{27}$; Le Billon, $2001^{28}$; Ross, $2006^{29}$ ). This line of research argue that since natural resources might provide rebels engaged in civil wars economic opportunities not present during peace time, the insurgents might prefer continued fighting over peace, which leads to increase in the duration of civil wars involving valuable natural resources. Thus, according to this line of research, natural resources directly increase the likelihood of civil conflicts and decrease the likelihood of peaceful resolution to the conflict. On the other hand, the indirect link stream of literature argues that resources abundance might in fact have a negative impact on regime stability and economic growth, which suggests a more indirect path to internal conflict duration (e.g. Sachs \& Warner, ${ }^{30}$ ). This phenomenon is referred to in the literature as the oil curse (Ross, $2006^{31}$ ) or the "Dutch disease" argument which claims that oil-dependent nations are more prone to long civil wars compared to less mineral-affluent countries.

These theoretical propositions have been confirmed empirically in several studies. For example Collier and Hoeffler (2004) ${ }^{32}$ found a nonlinear relationship between natural resources' dependence and internal conflict duration in a study spanning 78 civil wars. Similar results were reported in Smillie (2002) ${ }^{33}$ and Renner (2002) ${ }^{34}$. Koos and Basedau (2013) ${ }^{35}$ also found that 
uranium operations are significantly linked to civil war duration when interacting with ethnic exclusion. Aydin and Regan (2011) ${ }^{36}$ found countries with diamonds tend to have longer wars than others. This finding is supported in several Arab civil wars. For example, the existence of hydrocarbon reserves in southern Sudan conflict zone caused the civil war to last for quite a long time before the creation of the South Sudan republic. However, notable exceptions include studies by Elbadawi and Sambanis (2002) ${ }^{37}$ and Fearon and Laitin (2003) ${ }^{38}$. This discussion suggests the following hypothesis:

H5: The nearer the conflict to oil and valuable natural resources, the longer the duration of the civil war.

\section{Methodology}

\subsection{Data sources}

Data used in this study are taken from the UCDP/PRIO Armed Conflicts Dataset v. 3-2005. This dataset first appeared in Gleditsch, Wallensteen, Eriksson, Sollenberg and Strand (2002) ${ }^{39}$. It has subsequently been adapted for event history analysis by Gates and Strand (2004) ${ }^{40}$ and used in several research papers, including Buhaug, Gates and Lujala (2009) ${ }^{41}$. To our knowledge, this is the first research to use the dataset to analyze the duration of civil war in the Arab world. In our research we use the duration of civil war in the Arab world between 1948 and 2003, measured in days, as our dependent variable. The average duration of internal conflicts in the Arab world was 326 days and the most durable conflict is, not surprisingly, the Israeli-Palestinian conflict which exceeded 20,000 days by the end of 2003. Following Buhaug, Gates and Lujala (2009) ${ }^{42}$, coups d'etat conflicts were eliminated from the analysis since such conflicts are characterized by an armed conflict between two factions of government and have nothing to do with geopolitics.

\subsection{Measures}

Natural logarithm of the distance between the capital and the conflict zone was used as a measure of distance (Buhaug, Gates, \& Lujala, (2009) ${ }^{43}$ ). Following Buhaug and Gates (2009) ${ }^{44}$, distances were estimated using a geodesic measure. Rugged terrain was measured by the percentage of mountains and forests in the conflict zone. A dummy variable was used to code 
conflict zones near an international border. Because rebels operating far from the capital may not need to find a shelter in a neighboring country in order to avoid government forces, and since rebels with safe access to safe heavens nearby tend to be less dependent on bases in their home nation, we included an interaction term between distance and the existence of an international border. Rebels fighting capacity data were coded using Cunningham, Gleditsch, and Salehyan's (2009) ${ }^{45}$ classification which includes three categories (week, moderate, and strong). Following Buhaug, Gates and Lujala (2009) ${ }^{46}$, we operationalized this measure using a dichotomous variant since this was found to fit the data better. Finally, we code a dummy variable for the existence of oil in the conflict zone. This coding scheme is based on the work of Lujala, Rod and Thieme (2007) ${ }^{47}$.

\subsection{Self-organizing maps}

The SOM or Kohonen maps are basically artificial neural networks (NN) techniques used to explore and visualize hidden patterns in highly complex and multidimensional data. This method was first introduced to the artificial NN literature by Kohonen (1982) ${ }^{48}$. In fact SOM can be regarded as a clustering technique. Without resorting to the rigid assumptions of linearity or normality of traditional statistical techniques, these techniques aim at identifying different clusters in a large and complex data. Audrain-Pontevia (2006) ${ }^{49}$ argues that SOM is similar to the $k$-means clustering method in that it clusters data "based on an unsupervised competitive algorithm where each cluster has a fixed coordinate in a topological map". Thus an unsupervised training algorithm is used to train the SOM. In this training process no target output is provided and the network evolves until it convergence to a satisfactory solution. Lo \& Bavarian (1993) ${ }^{50}$ has used the Gladyshev's theorem to show that SOM models usually converge to an optimal solution..

The architecture of SOM is based on two layers, an input layer which classifies data based on their similarity, and an output layer responsible for self-organizing data in an ordered map where neurons with similar weights are organized together. The topology of the map is determined through the connections formed between adjacent neurons according to neighbourhood relations (Moreno et al. (2006) ${ }^{51}$. In fact Silven et al. (2003) ${ }^{52}$ argued that SOM can also be used for pattern classification since it merges information while preserving the most important topological and metrical relationships of the primary data elements on the display.

SOM is characterized by unsupervised character of learning algorithm and excellent visualization ability. Thus these models have been used in several clustering and classification tasks, including vehicle routing (Ghaziri \& Osman, $2006^{53}$ ), network intrusion detection (Zhong et al. $2007^{54}$ ), compounds pattern recognition (Yan, $2006^{55}$ ), classifying cognitive performance in schizophrenic and healthy individuals (Silver \& Shmoish, $2008{ }^{56}$ ), classifying magnetic resonance brain images (Chaplot et al. $2006{ }^{57}$ ), speech quality assessment (Mahdi, $2006{ }^{58}$ ), 
mutual funds classification (Moreno et al. $2006^{59}$ ), anomalous behavior in communication networks (Frota et al. $2007^{60}$ ), and market segmentation (Kuo et al. $2002^{61}$ ).

\subsection{Event history analysis}

As the name implies, event history or survival analysis looks at the time between events. This statistical technique was originally developed to study the time between medical intervention and death in order to demonstrate the usefulness of certain medical interventions (Drye, Wetherill \& Pinnock, 2001 ${ }^{62}$ ). The standard event history analysis applied to study the duration of civil conflicts has traditionally been either the Weibull regression model or the Cox Proportional Hazard Model (e.g. Cunningham, $2006{ }^{63}$ ). Assuming some underlying "hazard function" that determines the baseline duration, event history models test the impact of a set of covariates on the duration of internal conflicts. In this study we employ the Weibull accelerated failure-time (AFT) regression model, though we additionally employ the Cox Proportional Hazard Model for robustness check.

\section{Results}

\subsection{Kohonen maps}

We use Kohonen SOM in order to explore the influence of geopolitical factors on the duration of civil wars in the Arab world. Among the several available software packages developed to analyze SOM models, we chose SOMine package version 5.0 (Viscovery software, $2008{ }^{64}$ ). This software automatically finds the efficient SOM clusters by applying advanced artificial intelligence techniques. In order to visualize the resulting SOM cluster structure, the unified distance matrix ( $U$-matrix) has been used by some authors (e.g. Vijayakumar et al. $200{ }^{65}$ ). However, since it has been argued that this method might not result in a map with crisp boundaries to the clusters (Worner \& Gevrey, $2006^{66}$ ), we use in this study a hierarchical cluster analysis with a Ward linkage method in order to clearly delineate the boundaries of each resulting cluster. Kohonen (2001) ${ }^{67}$ has investigated two learning SOM algorithms. The first one is called the stochastic or sequential learning algorithm, while the second is known as the batch

learning algorithm. Following Ding \& Patra (2007) ${ }^{68}$, we choose the sequential learning algorithm to train the SOM since the sequential algorithm is stochastic in nature and is less likely trapped to a local minimum (reaching semi-optimal solution). 
Figure 1 shows the SOM cluster results. In this two-dimensional hexagonal grid we clearly see the division of the input pattern into three clusters. However for purposes of comparison we present both the SOM-Ward and the unified distance matrix ( $U$-matrix) results.

[Please insert Figure 1]

In this graph we can be read off patterns from the emerging landscape on the grid. For example, it can be seen that the green-colored cluster is the largest cluster with a frequency of $57.63 \%$. This is the mid-range civil war duration cluster. Arab civil wars in this cluster are characterized by medium distance to capital $(149 \mathrm{~km})$, medium rebels' fighting capability. Not surprisingly, this cluster is rich in oil and other valuable resources. The red-colored cluster represents the high duration civil war cluster. This cluster accounts for 28.39 per cent of internal conflicts in the Arab world. Civil wars in this cluster are characterized by easy access to an international border and high forest coverage. Table 1 summarizes the basic information in each cluster.

[Please insert Table 1]

Featuree or component maps can be constructed based on the SOM-Ward clusters (Vesanto, $2000{ }^{69}$ ). In these maps known in the literature also as "temperature maps" (Churilov \& Flitman, $2006^{70}$ ), nodes which share similar information are organized in close color proximity to each other. Feature maps show the distribution of values of the respective input component over the map. Resulting feature maps for every cluster and for all input attributes are shown in Figure 2. In this figure relationships between variables used in the study may be inspected by visually comparing the pattern of shaded pixels for each map. Thus, pattern similarity indicates strong relationships between the variables and vice-versa. In this figure the color scale at the bottom of shows that blue representsr low values, green represents mid-range values and red is used for high values. Finally, the name of input component used appears on top of each map.

\section{[Please insert Figure 2]}

From the feature maps we note, for example, that the extreme values represented in red in the Arab civil war feature map in the high duration cluster matches those extreme values found in the distance to capital and rich oil resources' feature maps. Interestingly, the low duration cluster includes the lowest constellation of red pixels in the oil resources attribute. Through the use of colour, one can immediately see that the distance portion is significantly larger than the rest in the distance (dist) window for the high duration cluster -thus implying that distance to capital is positively related to civil war duration- a result that was previously confirmed by other researchers (e.g. Buhaug, Gates \& Lujala, $2009^{71}$ ). In essence, these SOM maps reveal the 
existence of some theorized assumptions in the literature. It is also possible to find subgroups that do not follow the main theoretical assumptions in these maps. For example, a deviant subgroup might be detected when red dots are found in the middle of the green area. Similarly when two clearly separated areas are formed either by blue or red nodes, this might be considered as a sign of non-linear correlation (Thneberg \& Hotulainen, $2006^{72}$ ).

\subsection{Product-moment correlations}

Though it does not prove causation, correlation can serve as predictor of causation (Sekaran, $2000^{73}$ ). The product moment correlations between the variables are shown in Table 2. This table was constructed to get a feel for the associations among the six constructs constituting the model. Most of the correlation coefficients were significant and had the expected sign. Thus the constructs, in general, are highly related. However this result should be interpreted with some caution due to the large sample size.

[Please insert Table 2]

\subsection{Weibull and Cox proportional hazard regression models}

To formally test the research hypotheses, we conduct different specifications of the Weibull regression model. As a robustness check, we also employ the Cox proportional hazard regression model. However, since results obtained are virtually identical, we only report in Table 3 the Weibull AFT coefficients. These coefficients are fairly easy to interpret with positive values indicate longer civil war duration, and negative values imply shorter duration. Following Buhaug, Gates and Lujala (2009) ${ }^{74}$, robust $Z$ and robust standard error statistics are estimated by clustering observations on Arab countries. Although previous hazard models had identified several plausible factors that might affect the duration of civil wars, we only controlled for the post-cold war era (civil wars that occurred after 1989). We did not control for other variables such as GDP or regime type since GDP data are only available from 1951, so controlling for this variable means that we lose three years of observations. On the other hand, the Polity index suffers from an inherent "endogeneity problem" (Buhaug, Gates, and Lujala, $2009{ }^{75}$ ). Thus, because the end of Cold War also meant the end of several proxy wars in the Arab world, we control for post-cold war period in all models by using a dummy variable coded as 0 for the period before the end of Cold War (1989) and as 1 thereafter. It should be noted that we also did not control for ethnicity since the major divide between Sunni and Shia became evident only 
after the end of the Iraq war. STATA version 11 statistical package was used to conduct the analysis (Codes are in the Appendix).

From Table 3 we see that the four Weibull regression models confirm the hypothesized relationships related to civil war duration in the Arab world. For example, distance from the capital was found in all models to longer the duration of conflict, which confirms hypothesis 1. In model three, we see that access to international border increases the duration of civil conflict which supports hypothesis 2 . Forest coverage, but not mountain coverage, was found to lengthen the duration of internal conflicts in the Arab world, which supports hypothesis 3. Strong rebels' fighting capacity was found to shorten the duration of conflict, implying that weaker rebels make conflicts last longer, which supports hypothesis 4 . Although oil resources was found to increase the duration of war as anticipated in hypothesis 5, this relationship did not reach statistical significance.

[Please insert Table 3]

Similar conclusions were reached using the Kaplan-Meier survival estimates shown in Figure 3. This figure visualizes the survival functions for access to border, rebels fighting capability, and access to oil resources in the conflict zone. From this graph is clear that access to border, weak rebels and access to valuable resources increases the duration of oil conflict in the Arab world. For example the effect of access to international border implies that after almost a year (365 days), more than three-quarters of all civil conflicts in the Arab world are still active compared to around only one-quarter in case of no access to an international border. Similar conclusions might also be drawn regarding rebels fighting capacity and existence of oil.

[Please insert Figure 3]

\section{Discussion, limitations and future research}

In this study we aimed to contribute to the civil war duration literature by solely focusing on the geopolitical dynamics of internal conflicts in the Arab world. Our findings indicate that previously ignored geopolitical factors seem to play an important role in the duration of internal conflicts. More specifically, we find that distance, access to international borders, terrain, and rebels fighting capability are positively related to civil war duration in the Arab world. Although 
valuable natural resources such as oil was also found to be positively related to the duration of internal conflict, this variable did not reach statistical significance.

The pattern of our findings is generally in line with studies investigating duration of civil conflicts in other parts of the world (e.g. Buhaug and Lujala, ${ }^{76}$ ). The strong support for hypothesis 1 reflects inability of Arab governments to control peripheral regions remotely located from the power center. This is particularly true in cases in which insurgents are supported by local population. This finding is also in line with the theoretical claim, which argues that the ruling elite in the Arab world disregard remote events less critical to their political survival. The recent internal conflicts in both Libya and Syria attest to this fact. The positive relationship between access to international border and duration of civil conflict found in this research is also in line with the safe havens theory (Arreguin-Toft, $2005^{77}$ ) and the supportive ethnic kin theory (Salehyan, $2007^{78}$ ). The week rebels' link to civil war duration in the Arab world is also in line with previous research (e.g. Buhaug, Gates and Lujala, $2009^{79}$ ). The rough terrain hypothesis is partially supported as we find that forest, but not mountain, coverage to be positively related to the duration of civil conflict. In fact this variable has yielded previously mixed results. For example, Collier, Elliot, Hegre and Hoeffler (2003) ${ }^{80}$ reported no relationship between mountainous terrain and forest cover on one hand and the duration of 55 civil wars. However, DeRouen and Sobek (2004) ${ }^{81}$ showed that forest cover increases the risk of prolonged civil conflicts. These conflicting results might be attributed to the different terrain measures used across the different empirical studies. Finally, although we find that oil prolongs civil conflicts in the Arab world, this relationship was not statistically significant. Probably this result might be explained by the fact that oil is not easily exploited resource by the insurgents because oil fields in the Arab world are under the governments' tight security (The National, $2011^{82}$ ).

In this research we focused on some salient geopolitical variables in an attempt to understand factors playing a role in civil war duration in the Arab world. Future research may investigate the influence of other variables such as external intervention, the regime type, the level of development and the distribution of ethnic and religious composition on internal conflicts' duration in the Arab world. In fact there is a growing literature investigating the effect of external intervention on the duration of internal conflicts (e.g. Regan, $2002^{83}$ ). Such studies have found that third-part interventions are likely to prolong civil wars (e.g. Balch-Lindsay \& Enterline, $2000{ }^{84}$ ). Future research may test whether this result holds in the Arab World's civil wars. There is also a growing body of literature investigating whether religion plays a central or peripheral role in civil wars (e.g. Svensson, $2007^{85}$; Lai, $2006^{86}$ ). Future research may explore the relationship between religious beliefs and the duration of civil wars in the Arab world. Several other studies have used regime type and the level of economic development as standard 
variables related to civil wars (e.g. Hegre, Ellingsen, Gates and Gleditsch, $2001{ }^{87}$ ). Yet another stream of research has investigated the impact of foreign aid on the duration of civil wars (e.g. Renner, $2002^{88}$ ). This line of research has found a statistically significant negative effect of foreign aid flows on the probability of ongoing civil conflicts to continue. Future research may investigate whether this result holds in the Arab World's civil conflicts. Future research may also study the influence of such variables in the duration of internal conflicts in the Arab world. Population fractionalization across different ethnic and religious groups might also be an avenue for future research.

\section{Notes}

1. Cunningham, D. (2006). Veto players and civil war duration. American Journal of Political Science, 50, 875-892.

2. Buhaug, H., Gates, S., \& Lujala, P. (2009). Geography, rebel capability, and the duration of civil conflict. Journal of Conflict Resolution, 53, 544-569.

3. Lacina, B., \& Gleditsch, N. (2005). Monitoring trends in global combat: A new dataset of battle deaths. European Journal of Population, 21, 145-166.

4. Buhaug, H., \& Rod, J. (2006). Local determinants of African civil wars, 1970-2001. Political Geography, 25, 315-335.

5. Schutte, S., \& Weidmann, N. (2011). Diffusion patterns of violence in civil wars. Political Geography, 30, 143-152.

6. Fearon, J. (2004). Why do some civil wars last so much longer than others? Journal of Peace Research, 41, 275-301.

7. Herbst, J. (2000). States and power in Africa: Comparative lessons in authority and control. Princeton University Press, Princeton, NJ.

8. Buhaug, H., Gates, S., \& Lujala, P. (2009), Ibid.

9. Balch-Lindsay, D., \& Enterline, A. (2000). Killing time: The world politics of civil war duration, 1820-1992. International Studies Quarterly, 44, 615-642.

10. Buhaug, H., \& Gates, S. (2002). The geography of civil war. Journal of Peace Research, 39, 417-433.

11. Fearon, J., \& Laitin, D. (2003). Ethnicity, insurgency, and civil war. American Political Science Review, 97, 75-90.

12. Buhaug, H., \& Rod, J. (2006), Ibid. 
13. Rustad, S., Rod, J., Larsen, W., \& Gleditsch, N. (2008). Foliage and fighting: Forest resources and the onset, duration, and location of civil war. Political Geography, 27, 761-782.

14. Murdoch, J., \& Sandler, T. (2002). Economic growth, civil wars, and spatial spillovers. Journal of Conflict Resolution, 46, 91-110.

15. Ward, M., \& Gleditsch, K. (2002). Location, location, location: An MCMC approach to modeling the spatial context of war and peace. Political Analyst, 10, 244-260.

16. Buhaug, H., Gates, S., \& Lujala, P. (2009), Ibid.

17. FAO (2005). State of the world's forests 2005. Rome: Food and Agricultural Organization of the UN.

18. Ross, M. (2006). A closer look at oil, diamonds, and civil war. Annual Review of Political Science, 9, 265-300.

19. Buhaug, H. \& Lujala, P. (2005). Accounting for Scale: Measuring Geography in Quantitative Studies of Civil War, Political Geography, 24, 399-418.

20. Collier, P. \& Hoeffler, A. (2004). Greed and grievance in civil war. Oxford Economic Papers, 56, 563-595.

21. Rustad, S., Rod, J., Larsen, W., \& Gleditsch, N. (2008), Ibid.

22. Buhaug, H., Gates, S., \& Lujala, P. (2009), Ibid.

23. Cunningham, D., Gleditsch, K., \& Salehyan, I. (2009). It takes two: A dyadic analysis of civil war duration and outcome. Journal of Conflict Resolution, 53, 570-597.

24. Walter, B. (2006). Building reputation: Why governments fight some separatists but not others. American Journal of Political Science, 50, 313-330.

25. Addison, T., Le Billon, P., \& Murshed, S. (2002). Conflict in Africa: The cost of peaceful behavior. Journal of African Economies, 11, 365-386.

26. Auty, R. (2004). Natural resources and civil strife: A two-stage process. Geopolitics, 9, 2949.

27. Collier, P. \& Hoeffler, A. (2004), Ibid.

28. Le Billon, P. (2001). Angola's political economy of war: The role of oil and diamonds. African Affairs, 100, 55-80.

29. Ross, M. (2006), Ibid.

30. Sachs, J., \& Warner, A. (2001). The curse of natural resources. European Economic Review, 45, 827-838.

31. Ross, M. (2006), Ibid. 
32. Collier, P. \& Hoeffler, A. (2004), Ibid.

33. Smillie, I. (2002). Dirty diamonds: Armed conflict and the trade in rough diamonds. Fafo report 377, Fafo Institute for Applied Social Science, Oslo, Norway.

34. Renner, M. (2002). The anatomy of resource wars. Worldwatch paper 162, Worldwatch Institute.

35. Koos, C., \& Basedau, M. (2013). Does uranium mining increase civil conflict risk? Evidence from a spatiotemporal analysis of Africa from 1960 to 2008. Civil Wars, 15, 306-331.

36. Aydin, A. \& Regan, P. (2011). Networks of third-party interveners and civil war duration. European Journal of International Relations, 18, 573-597.

37. Elbadawi, I., \& Sambanis, N. (2002). How much war will we see? Explaining the prevalence of civil war. Journal of Conflict Resolution, 46, 307-334.

38. Fearon, J., \& Laitin, D. (2003), Ibid.

39. Gleditsch, N., Wallensteen, P., Eriksson, M., Sollenberg, M., \& Strand, H. (2002). Armed conflict 1964-2001: A new dataset. Journal of Peace Research, 39, 615-637.

40. Gates, S., \& Strand, H. (2004). Modelling the duration of civil wars: Measurement and estimation issues. Paper presented at the $5^{\text {th }}$ Pan-European International Relations Conference. The Hague, Netherlands (September).

41. Buhaug, H., Gates, S., \& Lujala, P. (2009), Ibid.

42. Buhaug, H., Gates, S., \& Lujala, P. (2009), Ibid.

43. Buhaug, H., Gates, S., \& Lujala, P. (2009), Ibid.

44. Buhaug, H., \& Gates, S. (2002), Ibid.

45. Cunningham, D., Gleditsch, K., \& Salehyan, I. (2009), Ibid.

46. Buhaug, H., Gates, S., \& Lujala, P. (2009), Ibid.

47. Lujala, P., Rod, J., \& Thieme, N. (2007). Fighting over oil: Introducing a new dataset. Conflict Management and Peace Science, 24, 239-256.

48. Kohonen, T. (1982). Self-organized formation of topologically correct feature maps. Biological Cybernetics, 43, 59-69.

49. Audrain-Pontevia, A. (2006). Kohonen self-organizing maps: A neural approach for studying the links between attributes and overall satisfaction in a services context. Journal of Consumer Satisfaction, Dissatisfaction and Complaining Behavior, 19, 128-137.

50. Lo, Z., \& Bavarian, B. (1993). Analysis of convergence properties of topology preserving neural networks. IEEE Transactions on Neural Networks, 11, 207-220. 
51. Moreno, D., Marco, P., and Olmeda, I. (2006). Self-organizing maps could improve the classification of Spanish mutual funds. European Journal of Operational Research, 147, 10391054.

52. Silven, O., Niskanen, M., \& Kauppinen, H. (2003). Wood inspection with non supervised clustering. Machine Vision and Applications, 13, 275-285.

53. Ghaziri, H. \& Osman, I. (2006). Self-organizing feature maps for the vehicle routing problem with backhauls. Journal of Scheduling, 9, 97-114.

54. Zhong, S., Khoshgoftaar, M., \& Seliya, N. (2007). Clustering-based network intrusion detection. International Journal of Reliability, Quality and Safety Engineering, 14, 169-187.

55. Yan, A. (2006). Application of self-organizing maps in compounds pattern recognition and combinatorial library design. Combinatorial Chemistry \& High Throughput Screening, 9, 473480.

56. Silver, H., \& Shmoish, M. (2008). Analysis of cognitive performance in schizophrenia patients and healthy individuals with unsupervised clustering models. Psychiatry Research, 159, 167-179.

57. Chaplot, S., Patnaik, L., \& Jagannathan, N. (2006). Classification of magnetic resonance brain images using wavlets as input to support vector machines and neural network. Biomedical Signal Processing and Control, 1, 86-92.

58. Mahdi, A. (2006). Perceptual non-intrusive speech quality assessment using a self-organizing map. Journal of Enterprise Information Management, 19, 148-164.

59. Moreno, D., Marco, P., and Olmeda, I. (2006), Ibid.

60. Frota, R., Barreto, G., \& Mota, J. (2007). Anomaly detection in mobile communication network using the self-organizing map. Journal of Intelligent and Fuzzy Systems, 18, 493-500.

61. Kuo, R., Ho, L., \& Hu, C. (2002). Integration of self-organizing feature map and K-means algorithm for market segmentation. Computers \& Operations Research, 29, 1475-1493.

62. Drye, T., Wetherill, G., \& Pinnock, A. (2001). Donor survival analysis: An alternative perspective on lifecycle modelling. International Journal of Non-profit and voluntary Sector Marketing, 6, 325-334.

63. Cunningham, D. (2006), Ibid.

64. Viscovery Software GmbH (2008), SOMine user's manual version 5.0, Vienna, Austria.

65. Vijayakumar, C., Damayanti, G., Pant, R. \& Sreedhar, C. (2007). Segmentation and grading of brain tumors on apparent diffusion coefficient images using self-organizing maps. Computerized Medical Imaging and Graphics, 31, 473-484.

66. Worner, S., \& Gevrey, M. (2006). Modeling global insect pest species assemblages to determine risk of invasion. Journal of Applied Ecology, 43, 858-867.

67. Kohonen, T. (2001). Self-organizing maps. $3^{\text {rd }}$ Ed., Springer, Berlin. 
68. Ding, C., \& Patra, J. (2007). User modelling for personalized web search with selforganizing map. Journal of the American Society for Information Science and Technology, 58, 494-507.

69. Vesanto, J. \& Alhoniemi, E. (2000). Clustering of the self-organizing map. IEEE Transactions on Neural Networks, 11, 586-600.

70. Churilov, L., \& Flitman, A. (2006). Towards fair ranking of Olympics achievements: The case of Sydney 2000. Computers \& Operations Research, 33, 2057-2082.

71. Buhaug, H., Gates, S., \& Lujala, P. (2009), Ibid.

72. Thneberg, H., \& Hotulainen, R. (2006). Contributions of data mining for psycho-educational research: What self-organizing maps tell us about the well-being of gifted learners. High Ability Studies, 17, 87-100.

73. Sekaran, U. (2000). Research methods for business: A skill-building approach. Prentice Hall: New Jersey.

74. Buhaug, H., Gates, S., \& Lujala, P. (2009), Ibid.

75. Buhaug, H., Gates, S., \& Lujala, P. (2009), Ibid.

76. Buhaug, H. \& Lujala, P. (2005), Ibid.

77. Arreguin-Toft, I. (2005). How the weak wins the war: A theory of asymmetric conflict. Cambridge University Press, Cambridge.

78. Salehyan, I. (2007). Transnational rebels: Neighboring states as sanctuary for rebel groups. World Politics, 59, 217-242.

79. Buhaug, H., Gates, S., \& Lujala, P. (2009), Ibid.

80. Collier, P., Elliot, L., Hegre, H. \& Hoeffler, A. (2003). Breaking the conflict trap: Civil war and development policy. Oxford University Press, Oxford.

81. DeRouen, K., \& Sobek, D. (2004). The dynamics of civil war duration and outcome. Journal of Peace Research, 41, 303-320.

82. The National (August 18, 2011). Smugglers of petrol hold key to civil war, p. 7.

83. Regan, P. (2002). Third party interventions and the duration of interstate conflicts. Journal of Conflict Resolution, 46, 55-73.

84. Balch-Lindsay, D., \& Enterline, A. (2000).

85. Svensson, I. (2007). Fighting with faith: Religion and conflict resolution in civil wars. Journal of Conflict Resolution, 51, 930-949.

86. Lai, B. (2006). An empirical examination of religion and conflict in the Middle East. Foreign Policy Analysis, 2, 21-36. 
87. Hegre, H., Ellingsen, T., Gates, S., \& Gleditsch, N. (2001). Toward a democratic civil peace? Democracy, political change and civil war, 1816-1992. American Political Science Review, 95, 17-33.

88. Renner, M. (2002), Ibid. 
Figures and Tables

Figure 1. SOM-Ward and the $U$-matrix clusters
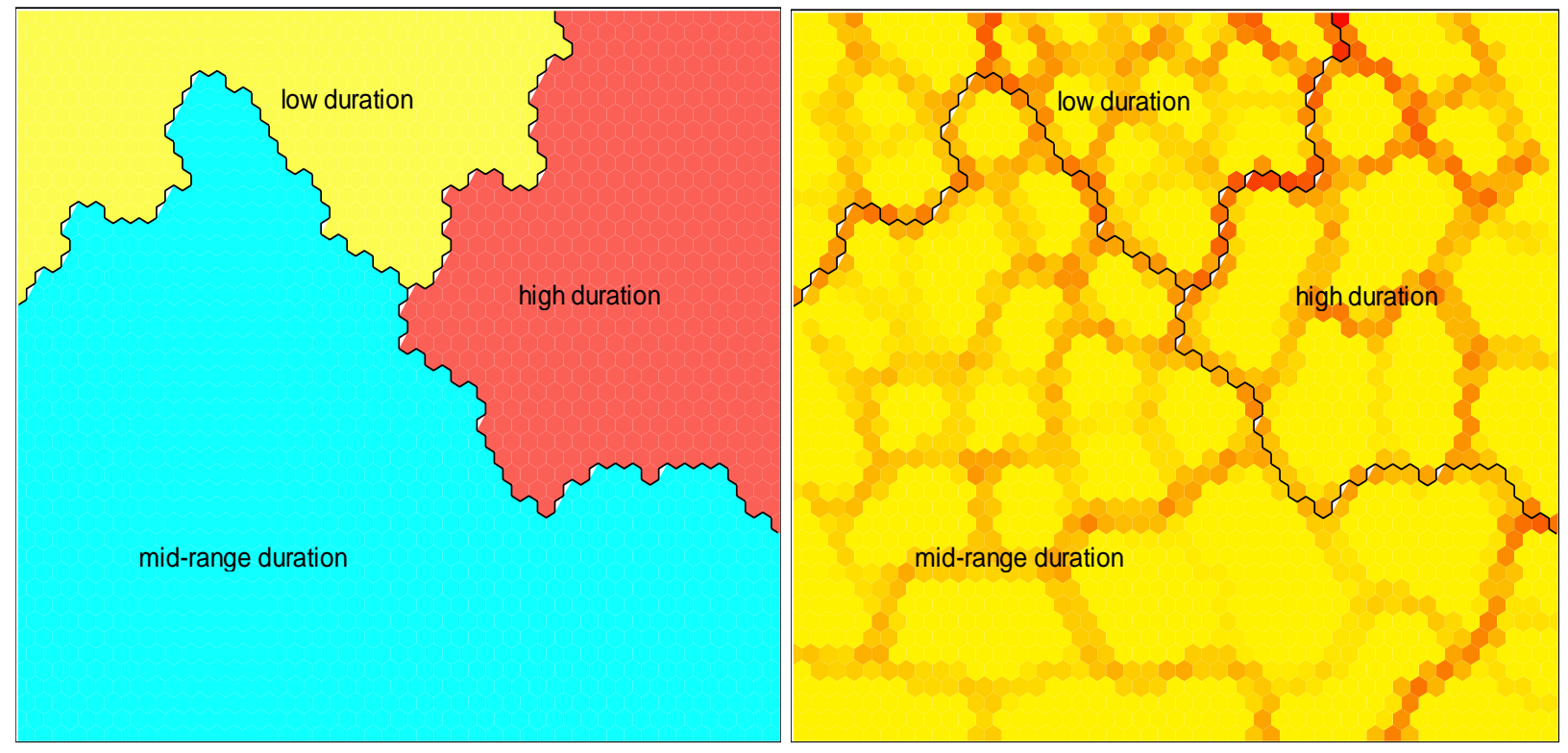
Figure 2. SOM Feature maps
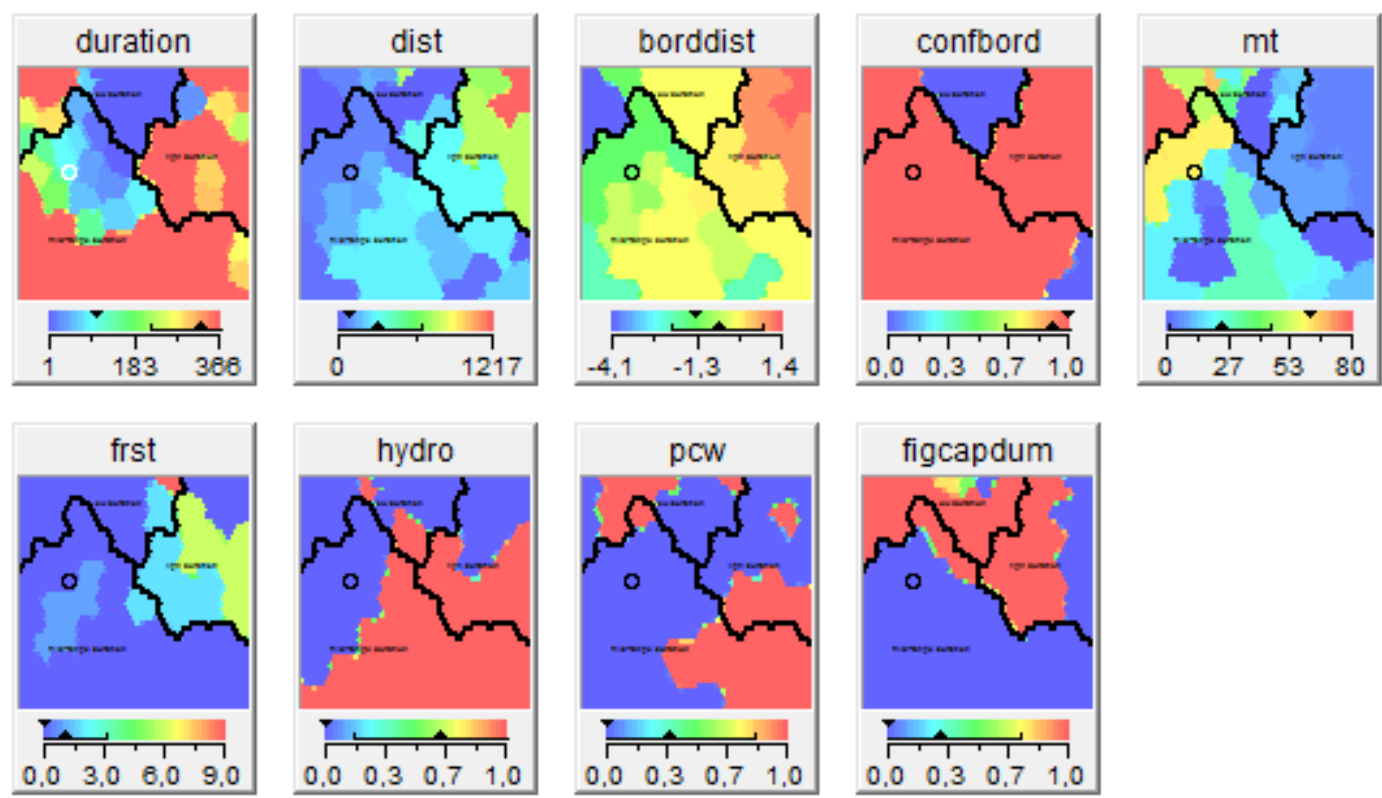


\section{Figure 3. Kaplan-Meier Survival Functions}
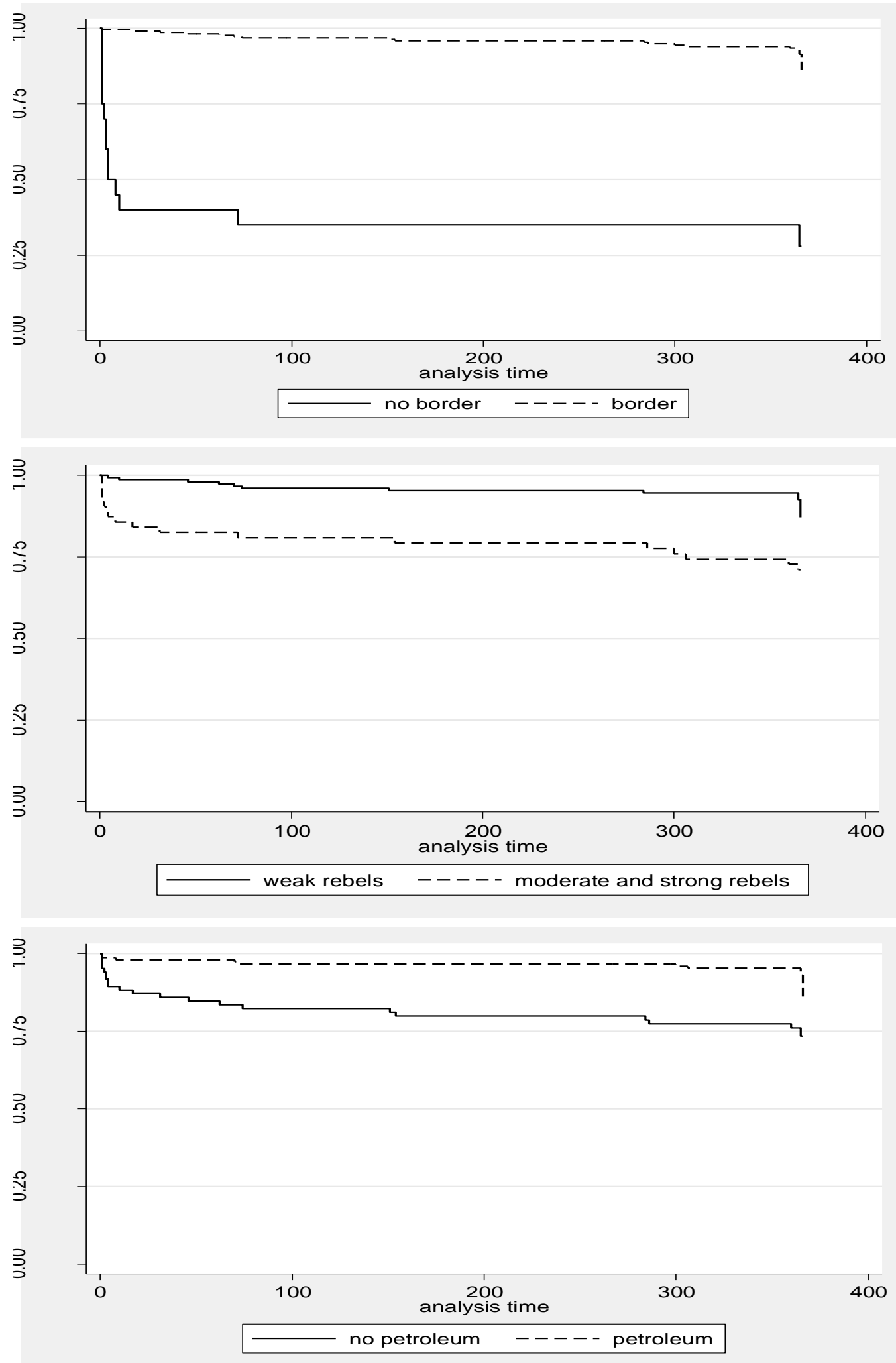
Table 1. Clusters summaries

\begin{tabular}{|c|c|c|c|c|c|c|c|c|c|c|}
\hline Segment & Frequency & duration & dist & borddist & confbord & $\mathrm{mt}$ & frst & hydro & pcw & figcapdum \\
\hline & & 335,9 & 149 & $-1,021$ & 0,949 & 24,35 & 0,051 & 0,816 & 0,338 & 0,025 \\
\hline $\mathrm{C} 2$ & $28,39 \%$ & 354,9 & 760 & 0,844 & 1,000 & 6,31 & 3,284 & 0,567 & 0,388 & 0,463 \\
\hline C 3: low & $13,98 \%$ & 223,6 & 61 & $-2,255$ & 0,636 & 54,03 & 0,394 & 0,091 & 0,273 & 0,933 \\
\hline
\end{tabular}


Table 2. Product moment correlations matrix

\begin{tabular}{|l|l|l|l|l|l|l|l|l|}
\hline & Dur & Dist & BordDist & ConfBord & Mt & Frst & Oil & FightCap \\
\hline Dur & 1 & & & & & & & \\
\hline Dist & $0.138^{*}$ & 1 & & & & & & \\
\hline BordDist & -0.059 & $0.788^{* *}$ & 1 & & & & & \\
\hline ConfBord & $0.560^{* *}$ & 0.125 & $-0.134^{*}$ & 1 & & & & \\
\hline Mt & -0.038 & $-0.502^{* *}$ & $-0.713^{* *}$ & 0.105 & 1 & & & \\
\hline Frst & 0.008 & $0.492^{* *}$ & $0.469^{* *}$ & 0.047 & $-0.360^{* *}$ & 1 & & \\
\hline Oil & $0.268^{* *}$ & $-0.165^{*}$ & 0.110 & 0.073 & $-0.386^{* *}$ & 0.031 & 1 & \\
\hline FightCap & $-0.227^{*}$ & -0.090 & $-0.186^{* *}$ & -0.132 & $0.257^{* *}$ & $0.179^{* *}$ & $-0.417^{* *}$ & 1 \\
\hline
\end{tabular}

$*$ Correlation is significant at the 0.05 level *(2-tailed)

** Correlation is significant at the 0.01 level $*(2$-tailed) 
Table 3. Event history analysis of Arab world's civil conflicts' duration (1948-2003)

\begin{tabular}{|c|c|c|c|c|}
\hline Variable & Model 1 & Model 2 & Model 3 & Model 4 \\
\hline Distance (ln) & 0.173 & $1.601 * * *$ & $1.058 * * *$ & $1.531^{* * * *}$ \\
\hline Border conflict & 2.349 & 0.697 & $2.713 * * *$ & 0.291 \\
\hline Distance x Border & -0.224 & $-1.632 * * *$ & $-1.096 * * *$ & $-1.931 * * *$ \\
\hline Rebels' Fighting Capability & & -0.765 & -1.172 & $-0.876 * * *$ \\
\hline Petroleum availability & & & 1.062 & 0.795 \\
\hline Mountains coverage (\%) & & & & -0.197 \\
\hline Forests coverage $(\%)$ & & & & $0.194 * * *$ \\
\hline Post-Cold War (1989) & -0.044 & -0.149 & -0.577 & -0.274 \\
\hline Constant & $5.513 *$ & $-1.858 * * *$ & $-1.532 * * *$ & -0.918 \\
\hline Log pseudo-likelihood & -105.393 & -78.553 & -74.304 & -75.216 \\
\hline Number of observations & 227 & 206 & 206 & 206 \\
\hline Number of failures & 25 & 21 & 21 & 21 \\
\hline Wald Chi-square & 4.51 & 1225.43 & 1199.42 & 1743.47 \\
\hline Prob. > Chi-square & 0.341 & 0.000 & 0.000 & 0.000 \\
\hline
\end{tabular}

${ }^{*} p<.10^{* *} p<.05{ }^{* * *} p<.01$ 